\title{
Perceived Economic Valuation of Selected Edible Forest and Wildlife Resources in Nsukka zone of Enugu State, Nigeria
}

\author{
Ijeomah, H.M. \& Ugwu, C.C. \\ Department of Forestry and Wildlife Management, University of Port Harcourt, P.M.B. 5323 \\ Port Harcourt, Nigeria. \\ henry.ijeomah@uniport.edu.ng; henryijeomah@yahoo.com
}

\begin{abstract}
Edible forest and wildlife resources are marketed in every part of eastern Nigeria but their perceived economic values and marketing channels in Nsukka rural communities of Enugu state is yet to be documented. Data used for the study were collected through oral interview, focus group discussion and administration of two sets of structured questionnaire. Oral interview was conducted with selected individuals from the communities who have been involved in the utilization and marketing of edible forest and wildlife products. One focus group discussion separated by gender and age was conducted in each community. Two sets of questionnaire were administered in the six communities. First set of questionnaire was administered to 120 full- time marketers while the second set was administered to 120 part-time marketers and consumers. A total of 240 respondents were sampled using questionnaire. Data collected were analyzed using descriptive statistics such as frequencies and percentages while Chi-square was used to test for associations. Result showed that Parkia biglobosa was cumulatively ranked first in the order of demand in the three local government areas surveyed. Other species with high cumulative demand included Pentaclethra macrophylla, Irvingia species and Anacadium occidentale. The cumulative demand rank of species on local government basis was closely related to their cumulative rank in terms of income generation. However, in Igbo Etiti local government area Parkia biglobosa was ranked second while Cola acuminata was ranked first. In the case of wildlife resources, honey was the most demanded edible wild resource in the local government areas except in Igbo Etiti where bushmeat ranked first. In income generation, most respondents ranked honey first in the three local government surveyed. On community basis Parkia biglobosa and honey were still the most demanded edible forest and wildlife resources respectively. Result from focus group discussion included Parkia biglobosa, Pentaclethra macrophylla, Irvingia species, honey, Cola acuminata and bush meat among products of high economic importance in the study area. Irvingia excelsa was ranked first in Ohodo (95\%), Umuida (95\%) and Ozalla (90\%).Parkia biglobosa was ranked first in Onicha (65\%) and Obollo (60\%). Cola acuminata was ranked second by $85 \%$ of respondents in Ohodo and Ozalla respectively, and third by $80 \%$ of the respondents in Umuida. Bushmeat was ranked second in Onicha (80\%), ObolloAfor (75\%) and Orba (60\%) based on economic importance. Parkia biglobosa and honey were respectively among the most important species in the study area based on income generation. Parkia biglobosa, Irvingia garbonensis, Irvingiaexcelsa, Cola acuminata, Anacardium occidentale, Treculia africana, Nicotiana tabacum, Honey, snail and bushmeat were ranked very high in terms of profitability.
\end{abstract}

Keywords: Edible forest and wildlife resources, Economic value, income generation, Nsukka, Nigeria

\section{INTRODUCTION}

The high value placed on edible forest and wildlife resources by various users has stimulated their increased demand in many areas, thus creating markets for producers and sellers of the product at different levels and locations, overseas inclusive (Ijeomah et al. 2015). The involvement of households in business opportunities created by this increased demand has helped in employing many people including none users of edible forest and wildlife products. Attempts to increase revenue generation by marketers of these products, in the face of continuously increasing economic hardship instigated by rapid population increase have stimulated investigations for enhanced knowledge on ways of utilizing these species. Wildlife resources serve as a source of bush meat in many localities. Due to the increase in world population, there is tremendous demand for food including protein and minerals (Popoola, 2010). Forest resources are highly valued as source of natural medicine. All edible forest and wildlife resources are mostly considered as non-timber forest products (NTFPs). It is 
obvious that wood/ timber are not edible and thereby excluded.Utilization of these edible forest and wildlife resources varies from one region to another.

There is inadequate information on economic contributions of the edible forest and wildlife resources in households' economies of Nsukka inhabitants.

The specific objectives of this study are to:

1. assess the perceived economic values of these resources in the study area.

2. evaluate perceived profit generated from these resources in the study area.

\section{MeThodology}

\subsection{Study Area}

The study was carried out in three selected Local government areas of Nsukka zone, Enugu state (Figure 1). The local Government Areas are Igbo-Eze North, Igbo-Etiti and Udenu. Igbo-Eze North Local Government Area (L.G.A.) lies between latitude $6.59^{\circ} \mathrm{N}$ and $6.983^{\circ} \mathrm{N}$, and longitude $7.27^{\circ} \mathrm{E}$ and $7.450^{\circ} \mathrm{E}$. Igbo -Eze North L.G.A. is in the north of Enugu state, Nigeria. It borders Kogi State and Benue state. The headquarter of Igbo- Eze North is Enugu -Ezike - a large community made up of 36 villages. The Local Government has an area of $293 \mathrm{~km}^{2}$ and a total population of 259,431 at the 2006 census (NPC, 2006).

Igbo-Etiti Local Government Area is located between latitudes $6.40^{\circ} \mathrm{Nand} 6.667^{\circ} \mathrm{N}$, and longitudes $7.22^{\circ} \mathrm{E}$ and 7.3670E. It has an area of $325 \mathrm{~km}^{2}$ and total population of 209,248 at the 2006 census. The headquarter of Igbo- Etiti L.G.A. is located in Ogbede.Udenu Local Government Area lies between latitudes $6.55^{\circ} \mathrm{N}$, and $6.917^{\circ} \mathrm{N}$, longitudes $7.31^{\circ} \mathrm{E}$ and $7.517^{\circ} \mathrm{E}$. It has a total area of $248 \mathrm{~km}^{2}$ and a total population of 178,466 at the 2006 census. Its' headquarter is in Obollo-A for on the $\mathrm{A}_{3}$ highway.

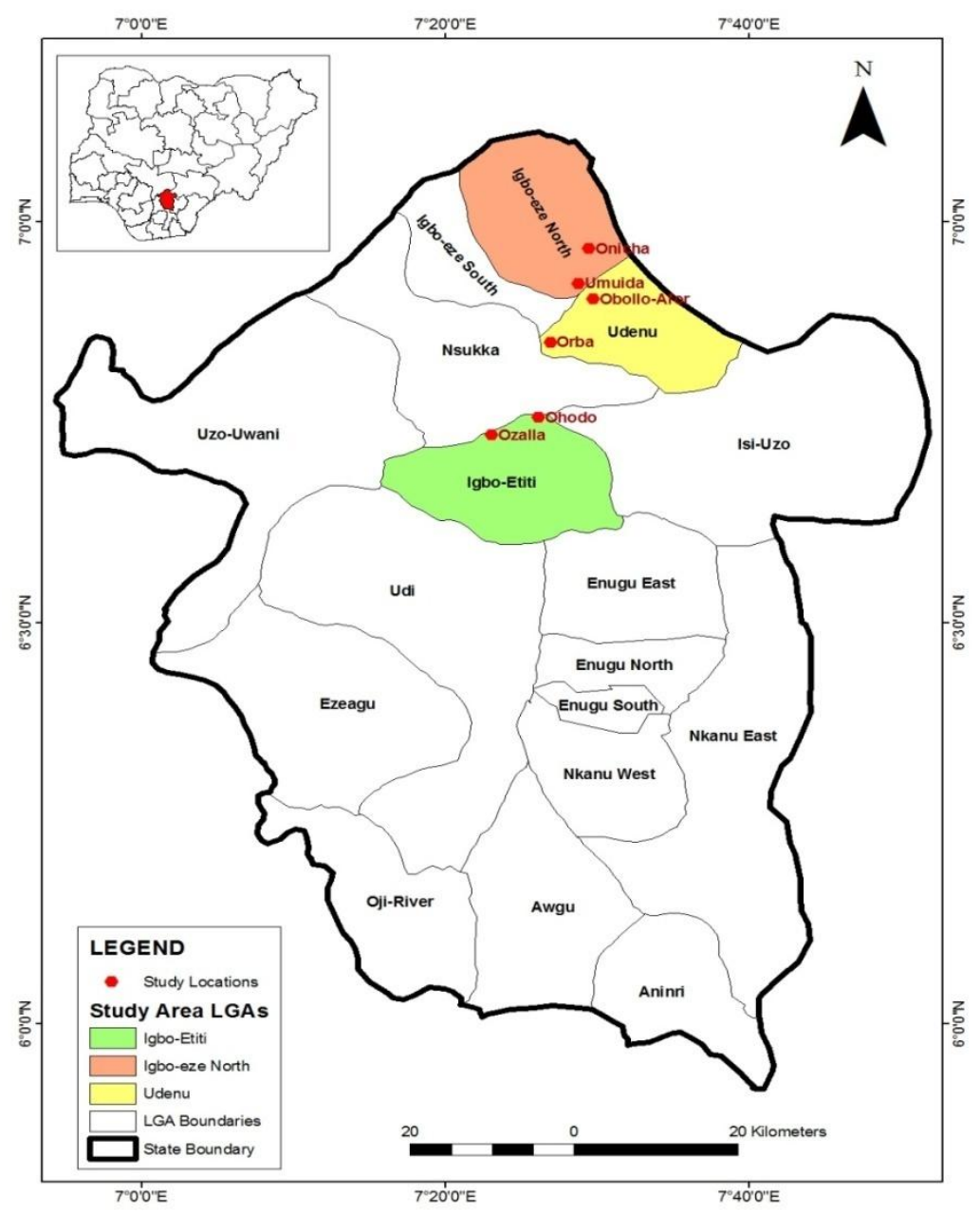

Figure1. Map of Enugu state showing the study sites

Source: Ijeomah and Ugwu (2016) 


\subsection{Sampling Procedure}

Three Local Government Areas were selected based on the availability of edible forest and wildlife resources in the area. The Local government areas are: Udenu L.G.A., Igbo-Etiti L.G.A, and Igbo-Eze North L.G.A. Two communities were selected from each of the three selected Local Government Area as was done by Ijeomah and Ugwu (2016).Six communities were selected in all. These communities are;Umuida and Onicha Enugu-Ezike communities from Igbo-Eze North L.G.A, Ohodo and Ozalla communities from Igbo-Etiti L.G.A, and Obollo-Afor and Orba communities from Udenu L.G.A. These six communities were selected based on the availability of edible forest and wildlife resources in the area.

\subsection{Methods of Data Collection}

Data for this research project were collected through oral interview, field observation, focus group discussion and administration of questionnaire. Oral interview was conducted with selected individuals (both men and women) from the communities who have been involved in marketing of edible forest and wildlife resources for a minimum period of five (5) years; and those involved in utilization of edible forest and wildlife resources for a minimum period of five years (5) respectively, and are therefore quite knowledgeable about marketing and utilization of edible forest and wildlife resources in the community.

Focus group discussions were organized to confirm information on utilization, marketing of forest and wildlife resources, seasonal variation in prices of products and profitability of resources collected through questionnaire. One focus group discussion separated by gender and age was conducted in each community. Twelve persons participated in each focus group discussion. Six of the group discussants in each community were males, and 6 were females. Three participants from each gender were below 25 years of age and were classified as youngs, while the other 3 participants were above 25 years and were classified as adults in the context of this work. Using the multiple needs ranking tools, priority needs were determined through consensus of answers by group discussants as was done by Omonona (2000), Hassan et al (2002) and Ijeomah (2007). A total of six focus group discussions were conducted, (i.e one from each community).

Two sets of questionnaire were administered. The first set was administered to part time marketers and consumers - those involved in utilization of edible forest and wildlife products and those who harvest and sell the products. Another set was administered to full time marketers as shown on Table .1a In the course of this work a full time marketer was defined as a person who always buys forest or wildlife product for re - selling whether processed or unprocessed, and has done so for a minimum period of five years (Ijeomah and Ugwu, 2016).

Table 1a: Allocation of questionnaire to respondents in selected communities

\begin{tabular}{llll}
\hline $\begin{array}{l}\text { Selected Local } \\
\text { Government Area }\end{array}$ & Selected Communities & $\begin{array}{l}\text { Number of respondents per of Questionnaire } \\
\text { A (For consumers) }\end{array}$ & B (For marketers) \\
\hline Igbo-Eze North & Umuida & 20 & 20 \\
& Onicha Enugu-Ezike & 20 & 20 \\
Igbo-Etiti & Ohodo & 20 & 20 \\
& Ozalla & 20 & 20 \\
Udenu & ObolloAfor & 20 & 20 \\
& Orba & $\mathbf{1 2 0}$ & $\mathbf{1 2 0}$ \\
\hline
\end{tabular}

\subsection{Data Analysis}

Data collected from the study were analyzed using descriptive statistics such as frequencies, percentages and means. Chi-square was used to test for degree of association between the age, educational status, income and storage of edible forest and wildlife resources.

\section{RESULTS}

\section{Perceived Economic Values of Forest and Wildlife Product}

Results on perceived economic values of forest and wildlife resources are presented in Tables $1 \mathrm{~b}$, Figure 2, Figure 3, Table 1b, Figure 4 and Figure 5. Parkia biglobosa was the most demanded species in most communities and was therefore cumulatively ranked first in the order of demand in the three local government areas surveyed (Table 1b). Other species with high cumulative demand in the three 
selected local government areas includes: Pentaclethra macrophylla, Irvingia species and Anarcadium occidentale (Table 1b). The cumulative demand rank of species on local government basis was closely related to their cumulative rank in terms of income generation. However, in Igbo Etiti local government area Parkia biglobosa was ranked second while Cola acuminata was ranked first. In the case of wildlife resources, honey was the most demanded edible wild resource in the local government areas (Table 1b) with exception of Igbo Etiti where bushmeat ranked first. In income generation, Table $1 \mathrm{~b}$ shows that most respondents ranked honey first in the three local government surveyed. On community basis Parkia biglobosa and honey were still the most demanded edible forest (Figure 2) and wildlife resources (Figure 3) respectively. Result from focus group discussion presented in Table 2 also included Parkia biglobosa, Pentaclethra macrophylla, Irvingia species, honey, Cola acuminata and bush meat among products of high economic importance in the study area. All the respondents ranked honey first in Orba community while $85 \%$ ranked it second in Obollo community. Irvingia excelsa was ranked first in Ohodo (95\%), Umuida (95\%) and Ozalla (90\%).Parkia biglobosa was ranked first in Onicha (65\%) and ObolloAfor (60\%). Cola acuminate was ranked second by $85 \%$ of respondents in Ohodo and Ozalla respectively,and third by $80 \%$ of the respondents in Umuida. Bushmeat was ranked second in Onicha (80\%), ObolloAfor (75\%) and Orba $(60 \%)$ based on economic importance. Figure 4 and Figure 5 show that Parkia biglobosa and honey are respectively among the most important species in the study area based on income generation.

Table 1b. Cumulative ranking of edible forest and wildlife resources based on income generation and peoples' demand in selected local government areas as indicated by respondents

\begin{tabular}{|c|c|c|c|c|c|c|c|c|c|c|c|c|c|}
\hline \multirow{2}{*}{$\mathbf{S} / \mathbf{N}$} & \multirow[t]{2}{*}{ FOREST RESOURCES } & \multicolumn{4}{|c|}{$\begin{array}{l}\text { IGBO-EZE NORTH L.G.A. } \\
\text { Umuida and Onicha }\end{array}$} & \multicolumn{4}{|c|}{$\begin{array}{l}\text { IGBO-ETITI L.G.A. } \\
\text { Ohodo and Ozalla }\end{array}$} & \multicolumn{4}{|c|}{$\begin{array}{l}\text { UDENU L.G.A. } \\
\text { Orba and Obollo-Afor }\end{array}$} \\
\hline & & Income & Rank & Demand & Rank & Income & Rank & Demand & Rank & Income & Rank & Demand & Rank \\
\hline 1 & Parkia biglobosa & 820 & $1^{\text {st }}$ & 835 & $1^{\text {st }}$ & 855 & $2^{\text {nd }}$ & 938 & $\mathbf{1}^{\text {st }}$ & 893 & $1^{\text {st }}$ & 894 & $1^{\text {st }}$ \\
\hline 2 & Pentaclethra macrophylla & 742 & $3^{\text {rd }}$ & 744 & $3^{\text {rd }}$ & 829 & $4^{\text {th }}$ & 859 & $2^{\text {nd }}$ & 696 & $4^{\text {th }}$ & 807 & $2^{\text {nd }}$ \\
\hline 3 & Irvingia garbonensis & 726 & $5^{\text {th }}$ & 711 & $4^{\text {th }}$ & 763 & $5^{\text {th }}$ & 782 & $3^{\text {rd }}$ & 618 & $6^{\text {th }}$ & 663 & $4^{\text {th }}$ \\
\hline 4 & Irvingia excelsa & 746 & $2^{\text {nd }}$ & 773 & $2^{\text {nd }}$ & 841 & $3^{\text {rd }}$ & 778 & $4^{\text {th }}$ & 716 & $3^{\text {rd }}$ & 757 & $3^{\text {rd }}$ \\
\hline 5 & Persea americana & 339 & $15^{\text {th }}$ & 311 & $16^{\text {th }}$ & 458 & $14^{\text {th }}$ & 561 & $11^{\text {th }}$ & 335 & $18^{\text {th }}$ & 316 & $18^{\text {th }}$ \\
\hline 6 & Dacryodes edulis & 382 & $13^{\text {th }}$ & 354 & $13^{\text {th }}$ & 510 & $13^{\text {th }}$ & 501 & $13^{\text {th }}$ & 365 & $16^{\text {th }}$ & 408 & $14^{\text {th }}$ \\
\hline 7 & Garcinia cola & 541 & $8^{\text {th }}$ & 277 & $19^{\text {th }}$ & 519 & $12^{\text {th }}$ & 547 & $12^{\text {th }}$ & 447 & $10^{\text {th }}$ & 269 & $21^{\text {st }}$ \\
\hline 8 & Cola acuminata & 729 & $4^{\text {th }}$ & 636 & $5^{\text {th }}$ & 897 & $1^{\text {st }}$ & 704 & $6^{\text {th }}$ & 757 & $2^{\text {nd }}$ & 757 & $3^{\text {rd }}$ \\
\hline 9 & Vernonia amygdalina & 286 & $18^{\text {th }}$ & 568 & $7^{\text {th }}$ & 415 & $16^{\text {th }}$ & 621 & $9^{\text {th }}$ & 215 & $21^{\text {st }}$ & 493 & $10^{\text {th }}$ \\
\hline 10 & Anacardium occidentale & 577 & $7^{\text {th }}$ & 587 & $6^{\text {th }}$ & 725 & $6^{\text {th }}$ & 690 & $7^{\text {th }}$ & 622 & $5^{\text {th }}$ & 468 & $11^{\text {th }}$ \\
\hline 11 & Dialium guineensis & 351 & $14^{\text {th }}$ & 351 & $14^{\text {th }}$ & 80 & $22^{\text {nd }}$ & 73 & $22^{\text {nd }}$ & 186 & $22^{\text {nd }}$ & 251 & $23^{\text {rd }}$ \\
\hline 12 & Chrysophyllum albidum & 487 & $10^{\text {th }}$ & 426 & $11^{\text {th }}$ & 420 & $15^{\text {th }}$ & 360 & $16^{\text {th }}$ & 507 & $7^{\text {th }}$ & 578 & $6^{\text {th }}$ \\
\hline 13 & Piper guineense & 444 & $11^{\text {th }}$ & 511 & $9^{\text {th }}$ & 311 & $18^{\text {th }}$ & 328 & $18^{\text {th }}$ & 367 & $15^{\text {th }}$ & 512 & $8^{\text {th }}$ \\
\hline 14 & Dinnettia tripetala & 404 & $12^{\text {th }}$ & 324 & $15^{\text {th }}$ & 411 & $17^{\text {th }}$ & 432 & $14^{\text {th }}$ & 395 & $14^{\text {th }}$ & 463 & $12^{\text {th }}$ \\
\hline 15 & Xylopia aethiopica & 212 & $21^{\text {st }}$ & 175 & $22^{\text {nd }}$ & 58 & $23^{\text {rd }}$ & 39 & $23^{\text {rd }}$ & 275 & $19^{\text {th }}$ & 327 & $17^{\text {th }}$ \\
\hline 16 & Tetracarpidium conophorum & 309 & $16^{\text {th }}$ & 448 & $10^{\text {th }}$ & 191 & $21^{\text {st }}$ & 181 & $21^{\text {st }}$ & 442 & $11^{\text {th }}$ & 398 & $16^{\text {th }}$ \\
\hline 17 & $\begin{array}{l}\text { Pterocarpus } \\
\text { soyauxii/mildbraedii } \\
\text { Pterocarpus santalinoides }\end{array}$ & 276 & $19^{\text {th }}$ & 529 & $8^{\text {th }}$ & 571 & $8^{\text {th }}$ & 629 & $8^{\text {th }}$ & 335 & $18^{\text {th }}$ & 641 & $5^{\text {th }}$ \\
\hline & & 155 & $22^{\text {nd }}$ & 200 & $21^{\text {st }}$ & 299 & $19^{\text {th }}$ & 313 & $19^{\text {th }}$ & 254 & $20^{\text {th }}$ & 283 & $19^{\text {th }}$ \\
\hline 19 & Treculia africana & 295 & $17^{\text {th }}$ & 210 & $20^{\text {th }}$ & 700 & $7^{\text {th }}$ & 709 & $5^{\text {th }}$ & 416 & $13^{\text {th }}$ & 502 & $9^{\text {th }}$ \\
\hline 20 & Afzelia africana & 9 & $24^{\text {th }}$ & 21 & $2^{\text {rd }}$ & - & - & - & - & 500 & $8^{\text {th }}$ & 278 & $20^{\text {th }}$ \\
\hline 21 & Nicotiana tabacum $L$. & 688 & $6^{\text {th }}$ & 303 & $17^{\text {th }}$ & 533 & $10^{\text {th }}$ & 332 & $17^{\text {th }}$ & 618 & $6^{\text {th }}$ & 518 & $7^{\text {th }}$ \\
\hline 22 & $\begin{array}{l}\text { Traditional medicines } \\
\text { (medicinal species) }\end{array}$ & 220 & $20^{\text {th }}$ & 284 & $18^{\text {th }}$ & 543 & $9^{\text {th }}$ & 617 & $10^{\text {th }}$ & 357 & $17^{\text {th }}$ & 423 & $13^{\text {th }}$ \\
\hline 23 & Canarium schweinfurthii & 516 & $9^{\text {th }}$ & 383 & $12^{\text {th }}$ & 521 & $11^{\text {th }}$ & 369 & $15^{\text {th }}$ & 440 & $12^{\text {th }}$ & 399 & $15^{\text {th }}$ \\
\hline 24 & $\begin{array}{l}\text { Brachystegia nigerica } \\
\text { WILDLIFE RESOURCES }\end{array}$ & 11 & $23^{\text {rd }}$ & 6 & $24^{\text {th }}$ & 269 & $20^{\text {th }}$ & 247 & $20^{\text {th }}$ & 464 & $9^{\text {th }}$ & 253 & $22^{\text {nd }}$ \\
\hline 1 & Honey & 279 & $1^{\mathrm{st}}$ & 253 & $1^{\text {st }}$ & 277 & $1^{\mathrm{st}}$ & 240 & $2^{\text {nd }}$ & 254 & $1^{\text {st }}$ & 244 & $1^{\text {st }}$ \\
\hline 2 & Bush meat & 217 & $2^{\text {nd }}$ & 224 & $2^{\text {nd }}$ & 240 & $2^{\text {nd }}$ & 255 & $1^{\text {st }}$ & 244 & $2^{\text {nd }}$ & 214 & $2^{\text {nd }}$ \\
\hline 3 & Guinea fowl & 1 & $7^{\text {th }}$ & 2 & $7^{\text {th }}$ & - & - & - & - & 144 & $4^{\text {th }}$ & 105 & $5^{\text {th }}$ \\
\hline 4 & Tortoise & 22 & $6^{\text {th }}$ & 21 & $5^{\text {th }}$ & - & - & - & - & 125 & $5^{\text {th }}$ & 137 & $4^{\text {th }}$ \\
\hline 5 & Pigeon & 23 & $5^{\text {th }}$ & 17 & $6^{\text {th }}$ & - & - & - & - & 94 & $6^{\text {th }}$ & 93 & $6^{\text {th }}$ \\
\hline 6 & Snail & 189 & $3^{\text {rd }}$ & 206 & $3^{\text {rd }}$ & 198 & $3^{\text {rd }}$ & 199 & $3^{\text {rd }}$ & 158 & $3^{\text {rd }}$ & 164 & $3^{\text {rd }}$ \\
\hline 7 & Edible termite & 116 & $4^{\text {th }}$ & 143 & $4^{\text {th }}$ & 104 & $4^{\text {th }}$ & 118 & $4^{\text {th }}$ & 57 & $7^{\text {th }}$ & 86 & $7^{\text {th }}$ \\
\hline
\end{tabular}

Source: Field survey, 2015. 
Perceived Economic Valuation of Selected Edible Forest and Wildlife Resources in Nsukka Zone of Enugu State, Nigeria

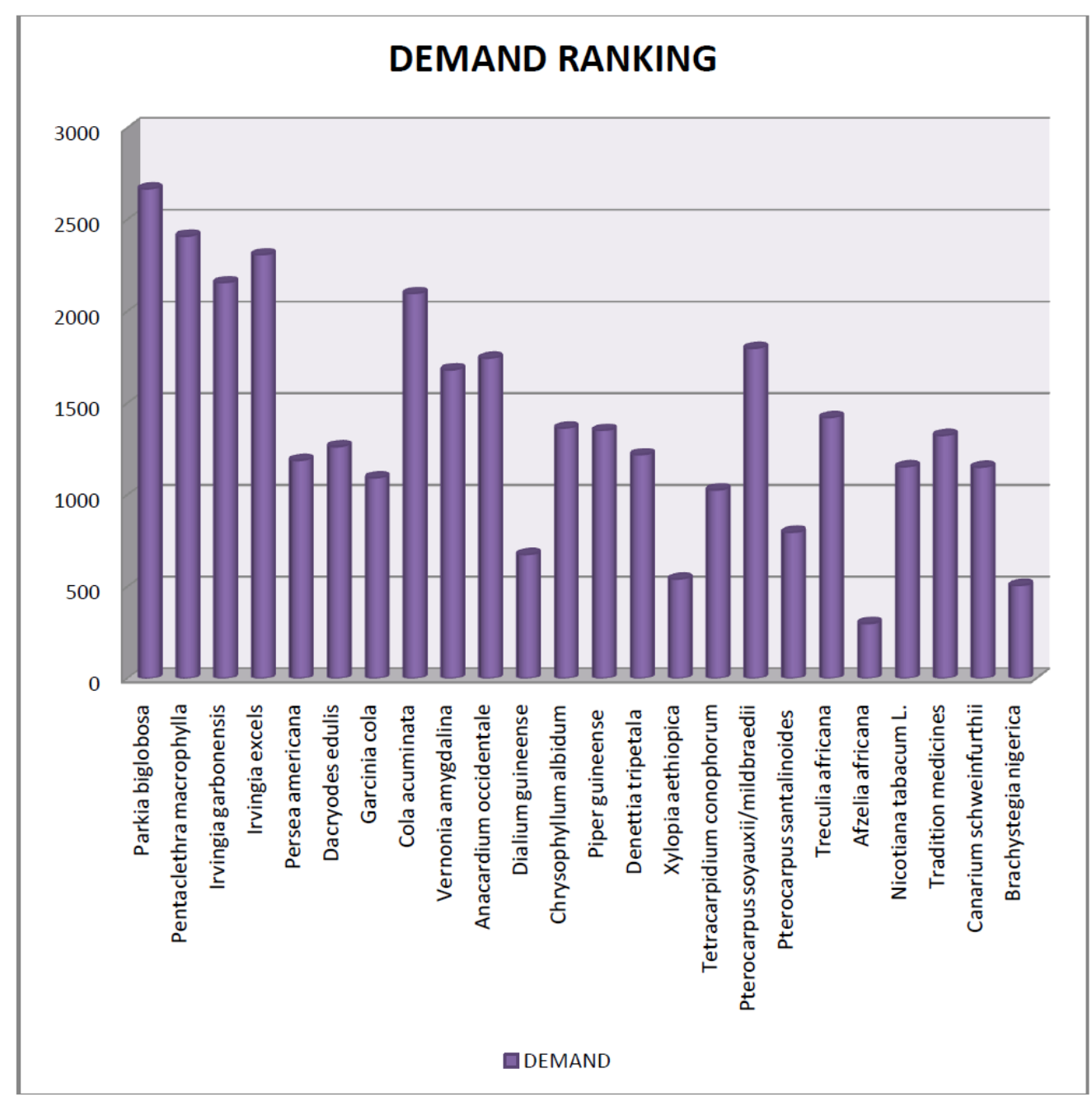

Figure2. Cumulative ranking of demand for edible forest resources in the six surveyed communities

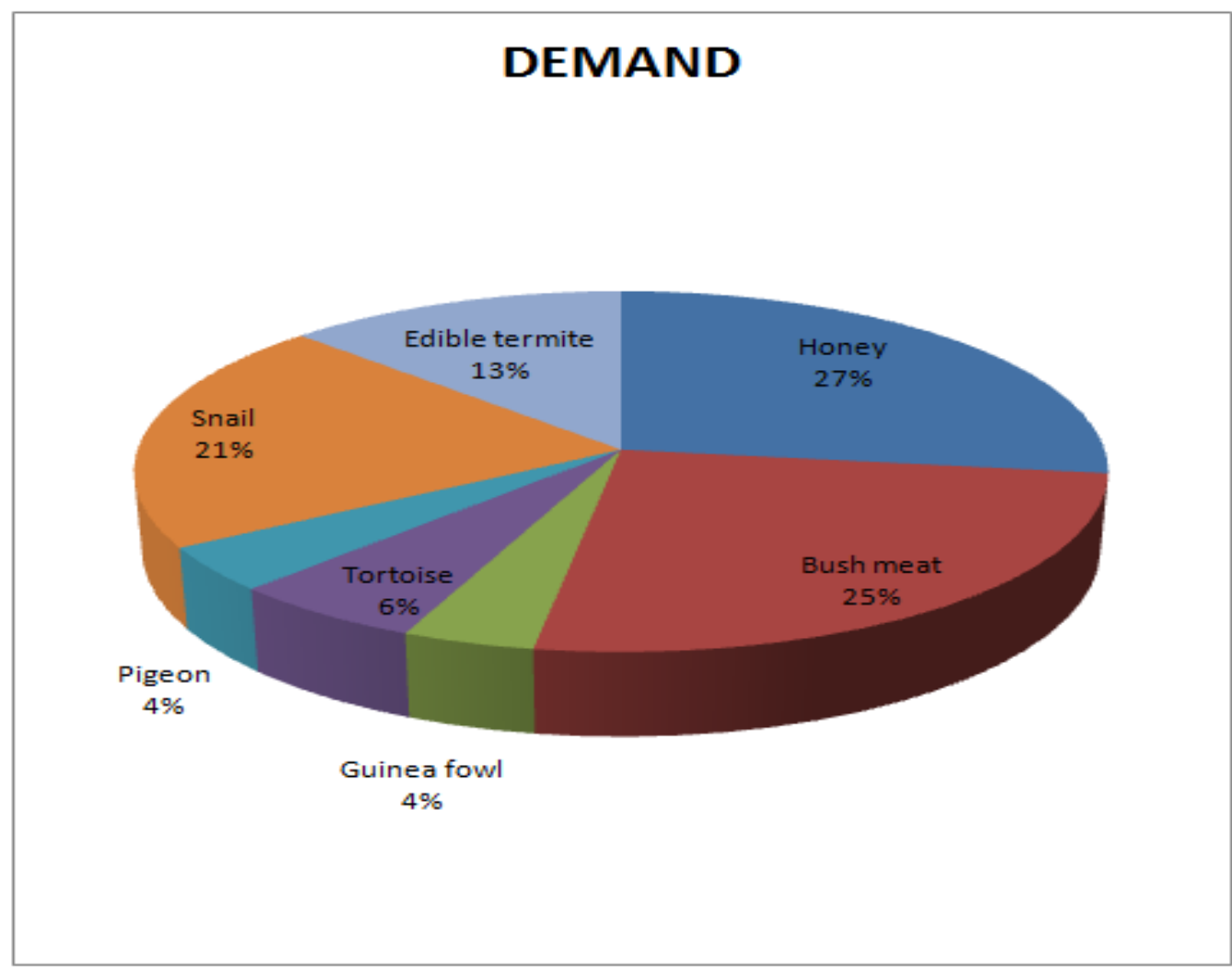

Figure3. Cumulative ranking of demand for edible wildlife resources in the studied six communities 
Ijeomah, H.M \& Ugwu, C.C.

Table2. Ranking of most important species in six selected communities based on economic importance as agreed in group discussions in the study area

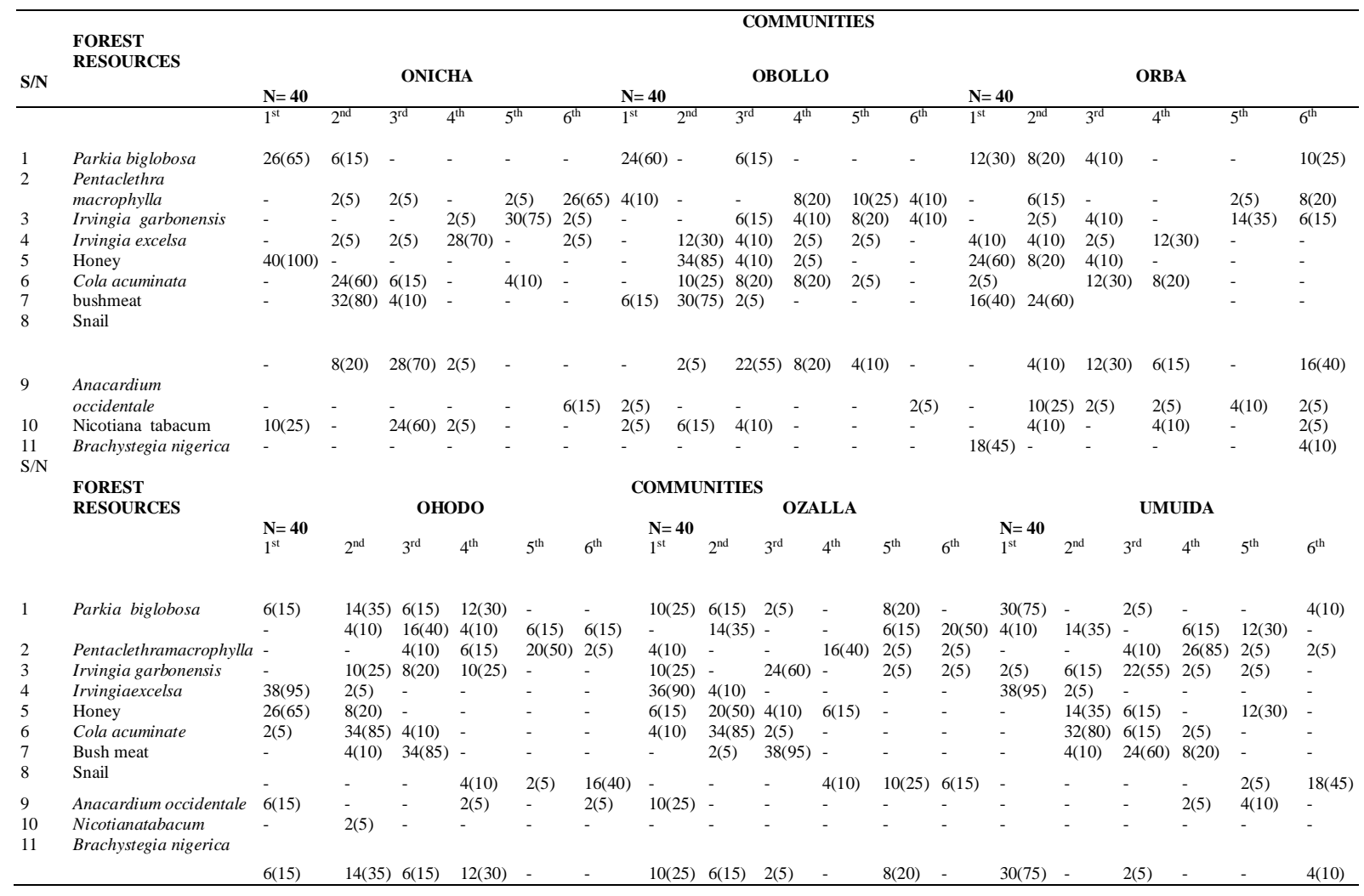

Source: Field survey, 2015.

$\mathrm{N}=$ Total no of respondents in each community

N/B: Numbers in parenthesis are percentage values.

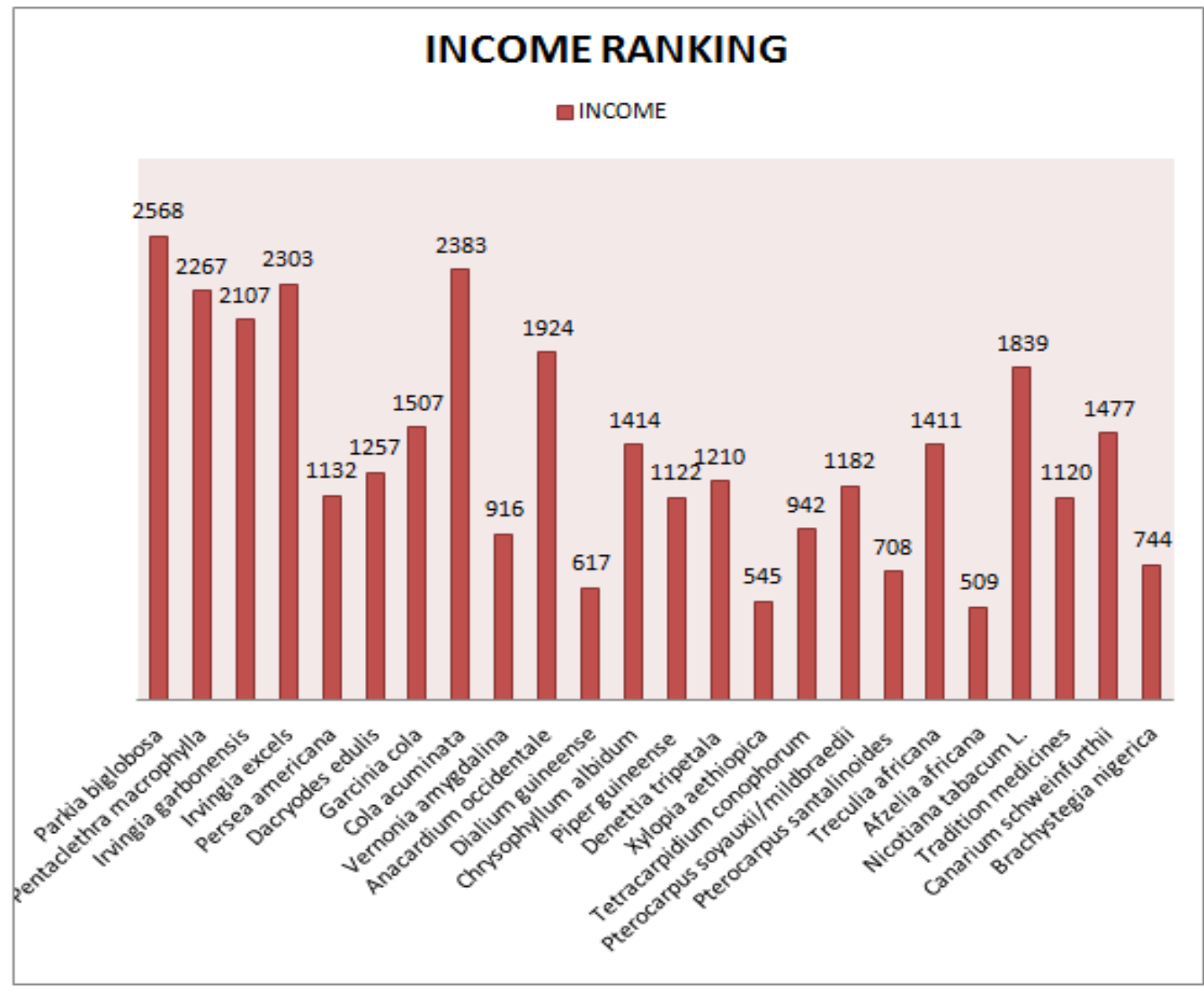

Figure 4. Perceived valuation of income generation from edible forest resources in the studied six communities 


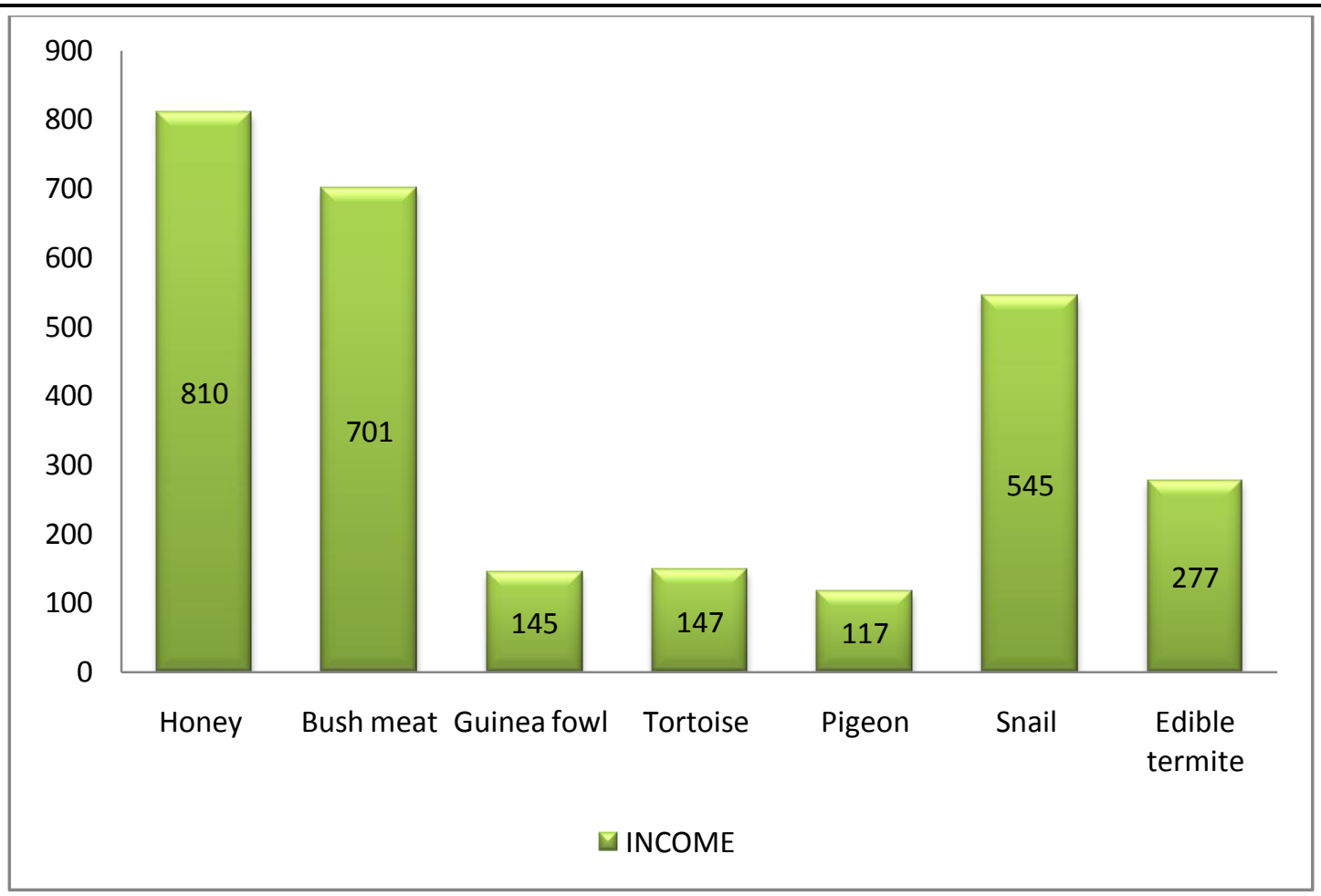

Figure5. Perceived valuation of income generation from edible wildlife resources in the studied six communities

\section{Seasonal Variation in Product Availability and Price}

According to Table 3 seasonal variations are experienced in the prices of most species due to relative abundance during on-season and shortage of supply during off season. Some species have no season, and can be found in the study area all the time.

Table3. Seasonal variation in prices of selected edible forest and wildlife resources in the study area as reported by focus group discussants

\begin{tabular}{|c|c|c|c|c|}
\hline $\mathbf{S} / \mathbf{N}$ & $\begin{array}{l}\text { Forest and wildlife } \\
\text { resources }\end{array}$ & $\begin{array}{l}\text { Common } \\
\text { Names }\end{array}$ & On-Season Selling Price (*) & Off-Season Selling Price (*) \\
\hline 1 & Parkia biglobosa & Locust bean & $\begin{array}{c}27 \text { milk cups(seed) - } 1000 \text { (Before } \\
\text { December) }\end{array}$ & $\begin{array}{c}20 \text { milk cups(seed)-1000 } \\
\text { (After December) } \\
\text { Same quantity-1,200 }\end{array}$ \\
\hline 2 & Pentaclethra macrophylla & Oil bean & $\begin{array}{l}\text { One small pent bucket- } 600 \text { (November) } \\
\text { A milk cup(seed)- } 100\end{array}$ & $\begin{array}{c}\text { (December) } \\
\text { Same quantity- } 250\end{array}$ \\
\hline 3 & Irvingia garbonensis & Bush mango & $\begin{array}{c}\text { (July) } \\
\text { A milk cup(seed)-200 }\end{array}$ & $\begin{array}{c}\text { (December) } \\
\text { Same quantity-500 }\end{array}$ \\
\hline 4 & Irvingia excelsa & --- & (December) & (July) \\
\hline 5 & Persea americana & Avocado & $\begin{array}{l}\text { Better quality, bought on stand- } 2,000 \\
\text { Better quality, bought on stand (normal } \\
\text { tree size) }-20,000\end{array}$ & Same as in on-season \\
\hline 6 & Dacryodes edulis & $\begin{array}{l}\text { Butter pear/ Native } \\
\text { pear }\end{array}$ & $\begin{array}{l}\text { Low quality, bought on stand } \\
\text { (medium/small sized tree)- } 8,000 \\
10-15 \text { seeds-50 }\end{array}$ & $\begin{array}{l}\text { Same as in on- season } \\
5 \text { seeds- } 50\end{array}$ \\
\hline 7 & Garcinia cola & Bitter kola & $\begin{array}{c}\text { (July) } \\
4 \text { seeds }-150\end{array}$ & $\begin{array}{l}\text { (before August) } \\
4 \text { seeds----300 }\end{array}$ \\
\hline 8 & Cola acuminata & Kolanut & (July) & \\
\hline 9 & Vernonia amygdalina & Bitter leaves & $\begin{array}{l}\text { One bundle, measured with hand---10 } \\
\text { (July) }\end{array}$ & $\begin{array}{c}\text { Same size---50 } \\
\text { (January--February) }\end{array}$ \\
\hline 10 & Anacardium occidentale & Cashew & $\begin{array}{c}\text { Fried cashew nut- A milk cup is } 50 \text { (March } \\
\text { - April) }\end{array}$ & $\begin{array}{l}\text { Fried cashew nut- A milk cup is 100- } \\
120 \text { (June/July) }\end{array}$ \\
\hline 11 & Dialium guineense & Black velvet & $\begin{array}{l}\text { A milk cup(pod): } 10 \\
\text { Bought on stand: } \\
\text { Low quality-5,000 }\end{array}$ & A milk cup(pod): 20 \\
\hline 12 & Chrysophyllum albidum & African star apple & $\begin{array}{c}\text { High quality--- } 15,000-20,000 . \quad[10 \\
\text { balls--50] }\end{array}$ & $\begin{array}{l}\text { Same as in on- season } \\
{[5 \text { balls--50] }}\end{array}$ \\
\hline 13 & Piper guineense & Black pepper & A milk cup(seed): 100 (July) & $\begin{array}{l}\text { A milk cup: } 200 \text { (November-- } \\
\text { December) }\end{array}$ \\
\hline 14 & Denettia tripetala & Pepper fruit & Bought on stand, normal sized tree $-4,000$ & Same as in on- season \\
\hline 15 & Xylopia aethiopica & Ethiopian pepper & It has no season in the study area & It has no season in the study area \\
\hline 16 & Tetracarpidium & African walnut & 4 processed Nuts (cooked): 20 & 3--4 processed Nuts (cooked): 20 \\
\hline
\end{tabular}




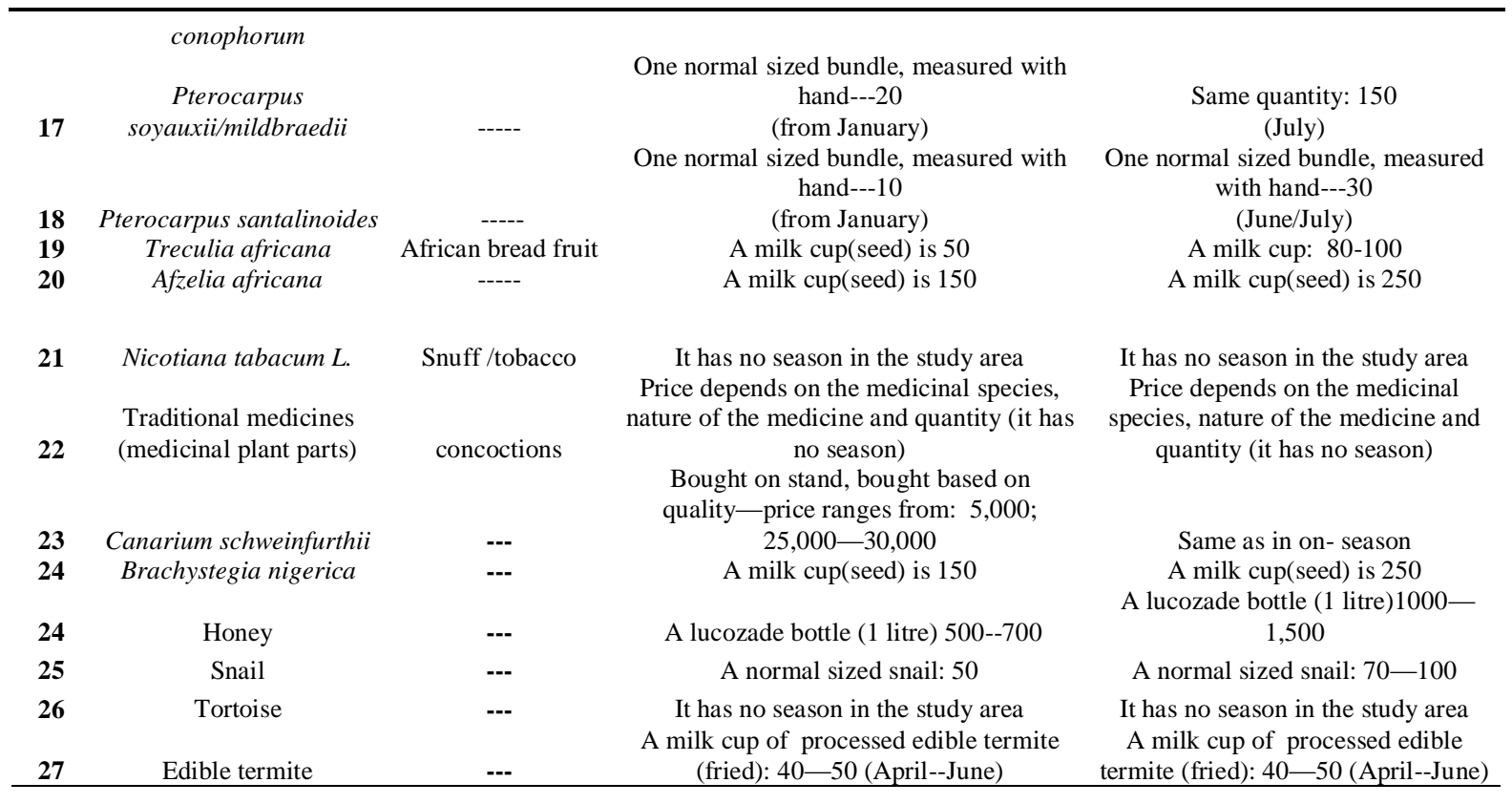

\section{Source: Field survey, 2015.}

N/B: * $220.00=1$ USD as at the time the study was conducted

Table 4 shows that Parkia biglobosa, Irvingia garbonensis, Irvingia excelsa, Cola acuminata, Anacardium occidentale, Treculia africana, Nicotiana tabacum, Honey, snail and bushmeat were ranked very high by focus group discussant in terms of profit generation to rural households in the study area.

Table4. Perceived Profitability level of products in the study area as ranked by focus group discussants

\begin{tabular}{|c|c|c|c|}
\hline \multicolumn{3}{|c|}{ Forest/Wildlife Resources } & \multirow[b]{2}{*}{ Profitability level } \\
\hline $\mathbf{S} / \mathbf{N}$ & & Common Names & \\
\hline 1 & Parkia biglobosa & Locust bean & Very high \\
\hline 2 & Pentaclethra macrophylla & Oil bean & Very high \\
\hline 3 & Irvingia garbonensis & Bush mango & Very high \\
\hline 4 & Irvingia excelss & --- & Very high \\
\hline 5 & Persea americana & Avocado pear & Low \\
\hline 6 & Dacryodes edulis & Butter pear/ Native pear & High \\
\hline 7 & Garcinia cola & Bitter kola & High \\
\hline 8 & Cola acuminata & Kolanut & Very high \\
\hline 9 & Vernonia amygdalina & Bitter leaves & Low \\
\hline 10 & Anacardium occidentale & Cashew & Very high \\
\hline 11 & Dialium guineense & Black velvet & Low \\
\hline 12 & Chrysophyllum albidum & African star apple & Low \\
\hline 13 & Piper guineense & Black pepper & Low \\
\hline 14 & Denettia tripetala & Pepper fruit & Low \\
\hline 15 & Xylopiaa ethiopica & Ethiopian pepper & Low \\
\hline 16 & Tetracarpidium conophorum & African walnut & High \\
\hline & Pterocarpus soyauxii/ & & Low \\
\hline 17 & mildbraedii & ----- & \\
\hline 18 & Pterocarpus santalinoides & ----- & Low \\
\hline 19 & Treculia africana & African bread fruit & Very High \\
\hline 20 & Afzelia africana & ----- & Low \\
\hline 21 & Nicotiana tabacum L. & Snuff /tobacco & Very High \\
\hline & Traditional medicines (medicinal & & \\
\hline 22 & plant parts) & Concoctions & Low \\
\hline 23 & Canarium schweinfurthii & --- & Low \\
\hline 24 & Brachystegia nigerica & --- & Moderate \\
\hline 25 & Honey & --- & Very High \\
\hline 26 & Snail & --- & Very High \\
\hline 27 & Tortoise & --- & Low \\
\hline 28 & Macrotermes natalensis & Edible termite & Low \\
\hline 29 & Bushmeat & - & Very High \\
\hline
\end{tabular}




\section{DISCUSSION}

\section{Perceived economic values of forest and wildlife products}

Income generation from marketing of edible forest and wildlife species in the study area differs. On cumulative ranking of demand and income generation for forest resources (Figure 2), the high ranking of Parkia biglobosa could be attributed to the fact that it is used as cultural condiment for cooking almost all types of traditional food in the study area. The fact that the species is not deliberately planted by respondents in the study area (Ijeomah and Ugwu, 2016) implies that the price will always be high as it is mostly sourced outside the study area especially, Anambra or Kogi state. The fact that it could only sprout and germinate by chance in the study area also means that the species is prone to be threatened. This agrees with Ijeomah and Ogara (2006) that most fruit trees in eastern Nigeria are threatened. Even if the existing trees in the study area fruits, the quantity most likely to be harvested can hardly be large enough for household to use and at the same time sells. The high demand with limited or seasonal availability culminates in high income generation to the sellers in the study area. People travel far and wide in search of Parkia biglobosa to buy due to the high price and income generation of this product. This is also the reason it is always traded on, stored and protected when found (the tree) in farms.

Another species of high economic value is Pentaclethra macrophylla. The species is used in preparing tapioca, a highly cherished cultural food among Ibo speaking areas of eastern Nigeria. The fact that tapioca has cultural significance in every occasion makes the demand very high (Table 1b). The high demand reflects in high income generation from the species. Ijeomah and Ogara (2006) obtained similar result in Ideator south of Imo state.

The seeds of Cola acuminata are consumed on daily basis and culturally used to welcome visitors. This makes it to have a high economic value in the study area (Table 1b). In terms of economic importance, it was rated first in Igbo Etiti local government area (Ohodo and Ozalla communities) (Table 1b), and second by many respondents in the same communities in overall economic importance (Table 2). The high economic rating could be attributed to the fact that many of the trees are found in the area. Households in Ohodo and Ozalla have been harvesting and trading on the fruits, and are therefore aware of the high profit margin between it and other species. It is also rated second and third in Orba and Obollo-Afor respectively. Marketers are aware of the high demand and revenue generated from the sales. The demand for Cola acuminata is a little lesser than that of Irvingia species but the value placed on it is higher because very few pods could easily be sold for high price. It is a major cash crop in the study area. Fruits of Cola acuminata and Irvingia species in family lands are occasionally harvested with money generated from the sales shared among many members of the family based on culture. The value placed on Cola acuminata is so high that owners guard the fruits jealously to ensure that nobody picks the ones that fall under gravity. This is different from other species like Chrysophyllum albidum, Persea americana, Dacryodes edulis and Canarium schweinfurthii which people could be allowed to pick the fallen fruits. When people pick the fallen fruit of Cola acuminata, they may be forced by the owner to drop them. Similar things happen in the case of Irvingia species, particularly Irvingia excela because of its high income generation to households and perceived economic value (Table 2). Irvingia excelais used as a soup thickener. It is a major source of revenue generation to many households in the study area especially during offseason. Irvingia excelsahas a bitter taste and therefore the fruit is less consumed (raw) than those of Irvingia gabonensis that has sweet fruits, however, kernels of the former are more valued as a soup thickener because of its consistent draw ability or slimy consistency. This agrees with Agbor (1986) that the bitter variety was more demanded than the sweet one. The demand for Irvingia species is very high as the species are part of the important diet of many Africans (Onyeike et al. 1995) .Irvingia kernels are dried, ground, packaged and sent to Nigerians in Europe and many parts of the world who cherish consumption of soup prepared with the species. This is done on regular basis. This corroborates earlier findings (Okafor, 1985; Okafor, 1991; Ladipo and Boland, 1994; Akubor, 1996; Ladipo, 1999; Ikhatua and Falodun, 2012) that Irvingia species generates high cash income within and outside Nigeria, and that the kernels are highly priced as soup condiments (Okafor, 1985; Okeke, 1995; Ikhatua and Falodun, 2012). The consumption of Irvingia seeds is limited by supply, and in urban areas, by high prices (Department of Forest Resource Management, Nigeria, 1986). 
Anacardium occidentale is a major cash crop in the study area. The fruits are frequently consumed while the seeds are processed for sale. Marketing of processed Anacardium occidentale seeds is an all season business in the study area especially Obollo -Afor community; which serve as a depot for the product. Processed seeds are sold along major access roads to travellers who buy and consume them as snacks. Marketers from many cities in southern Nigeria such as Aba, Enugu, Owerri, Onitsha, Okigwe and Port Harcourt travel to the study area to buy processed seeds of Anacardium occidentale. Consumption of processed seeds of Anacardium occidentale is cherished by many travellers, who also buy it as gift items for their relations. Treculia africana is rated $5^{\text {th }}$ and $7^{\text {th }}$ in Ohodo and Ozalla communities because the species is abundant therein and contributes a lot to household economies. Many marketers from Enugu town visit the communities to buy Treculia africana in large quantities as it is cherished by many diabetic patients. It is also a major source of income to respondents in the study area. Species like Xylopia aethiopica might still be needed by people but usually in smaller quantity and it therefore attracts lower income and might not worth people travelling to buy such product. In the case of tortoise, marketers travel to Kogi State (a far distance) to buy it yet, the price is very low in the study area, which culminates in lower income generation. The demand for Pterocarpussayauxii and Pterocarpusmilbraidii is high as vegetables always utilized for cooking cultural soup. The rate of income generation from the species could be high but the amount of revenue generated is relatively low. It was not listed among the six very important species in the study area.

In the case of edible wildlife resources honey, bush meat and snails are perceived to have high economic value in the study area. Honey production is a common business in the study area. Clay pots are commonly hung on trees in the study area as artificial hives to attract bees for honey production. Selling of honey and snail harvested from the wild is a major source of revenue to households in the study area. Baskets of snails could be freely collected from the wild and sold to generate income. Bush meat which is considered as a delicacy contributes economically to many local economies. Bushmeat, honey and snail are sources of income to respondents and were therefore highly valued in the study area. This agrees with the work of Ogogo et al (2010), and Onu and Ijeomah (2012). Irrespective of existing age-old legislations to protect endangered species, and the high rate of deforestation which has destroyed many wildlife habitat and reduced the productive ability of games, hunting and marketing of bushmeat remained a major source of income and employment to many respondents. Scarcity of bushmeat increases the value of available ones. Thus, bushmeat, honey and snails are sold along major access roads to the study area, special beer parlours, and restaurants and in community markets both in dry, fresh and cooked forms. This corroborates Asibey (1987a), Asibey (1987b) and Ajayi (1979) who reported that hunting and sales of bushmeat provide higher, though less secured income (and variety of needed products ) to local farmers in Nigeria than revenue generated from farming operations. This also agrees with the findings of Ntiamoa-Baidu (1987) in Ghana where bushmeat trade is the mainstay of local economies of many women.Bushmeat, when preserved by smoking or roasted could be supplied to cities within and outside Nigeria. This is the reason FAO (Undated) reported that bushmeat is valued throughout the West African region. Similarly, Ijeomah et al (2015) reported cases of poachers in Cross River National Park who spent weeks in the reserve, killing and roasting wild animals for sale. Consumption of bushmeat is limited by availability. Previously middle sized animal species were consumed by households while bigger ones were sold for revenue generation but presently small animals like squirrel could be sold due to the desire to generate revenue. The consumers can buy a small sized animal like squirrel due to the high demand for bushmeat. Awareness of health benefits of snail consumption is continuously creating more markets for snail sellers whereas all snail sold in the study area are sourced from the wild.

\section{Seasonal Variation in Price of Products and profit generation}

The desire to make more profit drives marketers to search and discover areas where products are abundant and cheap. These products are bought at cheap prices and sold directly to consumers, wholesalers, or to retailers at high profit margin. Parkia biglobosa is normally sourced from Onitsha or western part of Nigeria. However, some products sourced from distance areas could still be sold at cheap prices. Tortoise is sourced from Kogi state being a far distance area from Nsukka, yet its selling price ranges between \#300 and \#1,500 depending on sizes. A tortoise of 9inches in length sells for about \#1,000--\#1,500. Xylopia aethiopica could be sold as low as \#20--\#30 per wrap notwithstanding that it is mostly sourced from Kogi state. These show that apart from the desire to make high profit, 
marketers also try to fill market gaps. Since most respondents market many products, it becomes easy for marketers to cope when profit from different products are combined. This agrees with Oka for, 1989a and 1990a that forest products are sources of significant cash income for rural people. The fact that many products like Parkia biglobosa, Treculia africana, Pentaclethram acrophylla andIrvingia species are seasonal (Table 3) creates opportunity for marketers who have these products during offseason to sell at higher price and make more profit (Table 4). A milk cup full of Irvingia exclsa sold \#200 during on-season (December), sells for \#500 during off-season (after December); which is more than $100 \%$ increase in price. Similar increase in price during off-season is experienced in Garcinia cola, Cola acuminata, Parkia biglobosa, Treculia africana and Ptero carpus soyauxii(Table 3). Many of these seasonal products are bought during on-season and stored for sale during off-season. However, Pterocarpus soyauxiiis highly perishable and cannot be stored. Effective storage of the products is based on the indigenous knowledge and experience of respondents (Ijeomah and Ugwu, 2016), while the quantity stored per each species depends on respondents capital level.

More income is generated from species without alternatives during the off- season. Parkia biglobosa and Pentaclethram acrophylla will always be used for preparing cultural delicacies irrespective of the season of the year. Similarly, Treculia africana will always be utilized by many diabetic patients. Contrarily, people who could not afford Irvingia excels during the off - season because of the tremendously increased price may either switch over to other soup thickeners or reduce the quantity usually used at once by mixing the species with okro (another soup thickener that draws). It was on this basis that Department of Forest Resource Management, University of Ibadan (1986) attributed its consumption during the off - season as a luxury. The price of Irvingia excelsa is usually cheaper during the on -season but high every year during the off - season. Profit level from the marketing of some species (such as Pterocarpus soyauxii/ mildbraedii) could also be low but with high demand during off - season economics of large scale supply increases profit. The spread of availability of many products in the study area shows that there will always be resources to market at any season.

\section{CONCLUSION AND RECOMMENDATION}

Parkia biglobosa, Pentaclethram acrophylla, Treculia africana, Irvingia excelsa, Col a acuminata, Garcinia cola, Anarcardium occidentale, bushmeat, Irvingiag abonensis, Tetracarpidium conophorum, snailand honey were among species with high economic and profit values in the study area. The high economic values of these species extend to many parts of the world where these resources are utilized. The market for many of these species can hardly be exhausted due to limited availability, especially for the products of high economic values that are seasonal. This creates regular opportunities for sellers to make profit. Respondents should be encouraged to embark on large scale rearing of snails, grasscutters and giant rat for bushmeat production. Modern form of honey production should be introduced in the study area to increase productivity. Awareness should be created towards establishment of plantations for edible forest products in the study area.

\section{REFERENCES}

Agbor, L.O.N. ( 1986). Economic assessment of Irvingia gabonensis in Cross River State, Nigeria. MSc. Thesis, Department of Forest Resource Management, University of Ibadan, Ibadan, Nigeria

Ajayi, S.S. (1979). Utilization of forest wildlife in West Africa. Paper prepared for the FAO Forestry Department. FO:Misc./79/26

Akubor, P.I. (1996). The Suitability of African Bush Mango to Wine Production. Plant Food and Human Nutrition.49:213-219

Asibey, E.O.A. (1987a). The grasscutter. Forestry Commission, Accra, Ghana. Prepared for FAO Regional Office, Accra, Ghana.

Asibey, E.O.A. (1987b). Wildlife issues in sub-saharan Africa. Paper presented at the International Symposium and Conference: Wildlife Management in Sub-Saharan Africa, 6-12 October. Sponsored by FAO and the International Council for Game and Wildlife Conservation, Harare, Zimbabwe, pp. 32-50.

Department of Forest Resource Management, University of Ibadan. 1986. Feasibility study of indigenous forest fruit trees in Nigeria - Irvingia gabonensis, Parkia clappertoniana. Final Report. Prepared for the Federal Department of Forestry, Lagos, Nigeria. 
Ijeomah H.M. and Ogara I.M. (2006).Forest Resources Depletion and the Role of Rural Women in Selected Communities of Idea to South Local Government Area, Imo State. Journal of Production Agriculture and Technology, (PAT) 2 (2): 104-117. www.patnsukjournal.com.

Ijeomah, H. M., Oyebade, B.A.andMazi, E.C. (2015) utilization of edible winged termite (Macrotermes natalensis) in selected communities of Imo and Rivers states, Nigeria. International Journal of Scientific \& Engineering Research,6 (9):919 - 940, America

Ijeomah, H.M., Eniang, E.A. , Halidu, S.K. and Onyenekwe, A.N. (2015); Forms and Trends of Encroachments in Cross River National Park of Nigeria. International Journal of Biology;7 (3):103 -114, http://dx.doi.org/10.5539/ijb.v7n3p103.

Ijeomah, H.M. and Ugwu, C.C. (2016). Utilization of Selected Edible Forest and Wildlife resources in Nsukka Zone of Enugu State, Nigeria. Nigerian Journal of Agriculture, Food and Environment 12(1)

Ikhatua , M.I. and Falodun, A. (2012). The Essential Oil Components of Irvingia gabonensis and Irvingia wombolu from Southern Nigeria, Canadian Journal of Pure and Applied Chemistry 6( 2):1955-1959

Ladipo, DO. and Boland, DJ. (1994). Trade in Irvingia Kernels. In: Proceedings of the International Workshop on Irvingiain West Africa. Eds. Ladipo, DO. and Boland, DJ. International Centre for Research in Agro-Forestry (ICRAF), Nairobi, Kenya.98-112.

Ladipo, D.O. (1999). The Development of Quality Control Standards for Ogbono (Irvingia gabonensis and Irvingia wombolu) Kernel. In: Effects Towards Encouraging Organised and Further International trade in N.W.F.P. of West and Central Africa. Eds. Ladipo, DO. and Boland, D. J. Paper presented at NRI-IPGRI International workshop on African Indigenous Nuts, Limbe Cameroon. 22-28.

Ntiamoa-Baidu, Y. (1987). West African wildlife: a resource in jeopardy. Unasylva 156, 39(2):27-35.

Ogogo, A.U., Ijeomah, H.M. and Ekwere, I.F. 2010. Survey of Snail Farms in Cross River State, Nigeria, Global Approaches to Extension Practice, 6(1):48 - 57

Okeke, A. (1995). Nursery Observations on the Growth of Irvingia gabonensisvar excels (Ogbono) for small scale farmers. In: Forestry and the Small Scale Farmers. Ed. Oduwaiye, EA. Proc. of the $24^{\text {th }}$ Annual Conference of the Forestry Association of Nigeria (FAN), Kaduna. 247-253.

Okafor, JC. (1985).Commercial Production of 'Ogbono' and 'ugiri'. In: Information series on Agriculture in Anambra State. How to grow selected fruit trees. Booklet No. 4.25-30.

Okafor, J.C. (1989). Agro forestry aspects. Appendix No. 2 of Caldecott et al. 1989.Cross River National Park, Oban Division: Plan for developing the park and its support zone. Godalming. UK, WWF.

Okafor, J.C. (1990). Agroforestry development in the Boshi- Okwangwo Division of the Cross River National Park. Godalming, UK WWF.

Okafor, J.C. (1991). Importance of Indigenous Fruit trees in Nigerian Economy. Invited paper presented at the symposium marking the $11^{\text {th }}$ Food day celebration in Nigeria. Sheraton Hotel, Abuja. pp21.

Omonona, B.T. (2000): Poverty and its correlates among rural farming households in Kogi, Nigeria.Ph.D thesis. Department of agricultural Economics, University of Ibadan, Nigeria. 209pp.

Onu, M.E. and Ijeomah, H. M.( 2010). Assessment of Bushmeat trade in Ikwerre Local Government Area of Rivers State: A case Study of Omagwa Bushmeat market. International Journal of Agriculture and Rural Development13 (2): 281 - 286.

Onyeike, E.N., Olungwe, T. and Uwakwe, AA. (1995). Effect of Heat-treatment and Defatting on Proximate Composition of some Nigerian local Soup thickener. Food Chemistry

53:173-175.

Poopola, F.S., Abu, J.E., Isese, M.O., Ohenzuwa, U. B. and Isebemhe, E. (2010) Forestry a Veritable Tool for Food Security. Global Economic Crisis and Sus-tainable Renewable Natural Resources Manage-ment. Paper presented at the 33rd conference of Forestry Association of Nigeria (eds) Po-poola L, Idumah F.O, Adekunle, V.A.J., Azeez,. I.O Held in Benin-city, Edo state Nigeria between 25th- 29th October., Pp.456- 467 


\section{AUTHOR's BIOGRAPHY:}

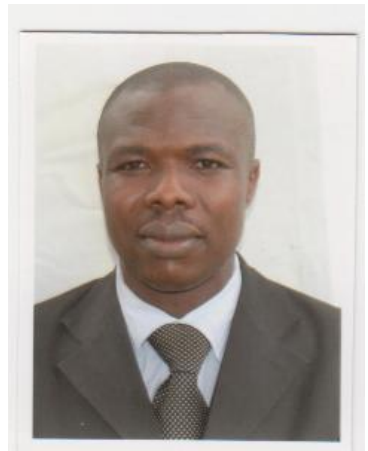

Dr. Henry Mmaduabuchi Ijeomah, holds a Bachelor of Agriculture Degree in Forestry and Wildlife Management from the University of Uyo, a Master and Doctorate degrees in Wildlife and Range Management from the University of Ibadan and a Master degree in Hospitality and Tourism Management from Imo State University, Owerri. At present, he is the Head, Department of Forestry and Wildlife Management, University of Port Harcourt. Dr. Ijeomah has taught Forestry, Wildlife Management, Tourism, and Biodiversity Conservation for many years at different academic levels including $\mathrm{Ph} . \mathrm{D}$. Dr . Ijeomah has published extensively in these fields.

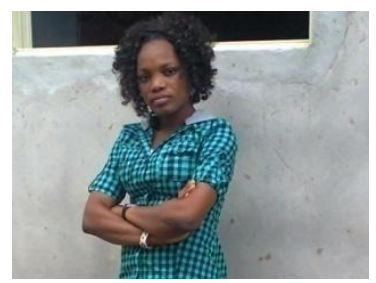

Ugwu Confidence Chiamaka, holds a Bachelor of Forestry and Wildlife Management degree from the University of Port Harcourt. She has conducted some studies in the area of edible Forest and Wildlife resources utilization. 